\title{
Pericardial Carcinomatosis
}

National Cancer Institute

\section{Source}

National Cancer Institute. Pericardial Carcinomatosis. NCI Thesaurus. Code C27385.

Carcinoma that has spread diffusely to the pericardium. 